\title{
The Constitutionality of DNA SAMPLing OF ARRESTEeS
}

\author{
By Anip Patel \\ Volume XIII - Fall 2012
}

\begin{abstract}
This article addresses whether the DNA Act (which requires DNA samples from arrestees) passes constitutional muster. I argue that the act is constitutional and that if society believes the collection of DNA from arrestees violates an individual's privacy, it should seek legislative resolution and not seek the protection of the Fourth Amendment of the Constitution. Throughout my analysis, I demonstrate why DNA collection is constitutional and how it is necessary. Part I of this article examines the history of DNA sampling, case law establishing an arrestee's expectation of privacy, and the applicable Fourth Amendment tests. Part II examines the arguments for and against DNA sampling by considering case law at the state and federal level, and explores the significance of junk DNA and the treatment of abandoned DNA. Part III is the personal analysis section, which argues that the totality of circumstances test is the proper test. I apply the test to determine that there is minimal intrusion of an arrestee's expectation of privacy through DNA sampling, a legitimate governmental interest, and that warrants are unnecessary. Further, the section demonstrates why DNA sampling is a natural progression from fingerprint collection, and the section analyzes abandoned DNA and DNA sampling. Part IV concludes the article by stating that the Fourth Amendment is not violated and that society must turn to Congress to seek greater protection.
\end{abstract}




\title{
The Constitutionality of DNA Sampling of ArRestees
}

\author{
By Anip Patel* \\ Volume XIII - Fall 2012
}

\section{INTRODUCTION}

Technological developments have changed the methods used by both criminals and law enforcement. As technology has improved, criminals have found new ways to carry out unlawful activity. In response, law enforcement has adopted modern technology to enhance its ability to combat crime. However, the use of improved methods to catch criminals to counterbalance the improved methods of committing crimes has raised constitutional concerns. For example, current legislation allows law enforcement to require any individual arrested of a crime — regardless of innocence or guilt — to provide a DNA sample, along with the usual fingerprint collection and mug shot. ${ }^{1}$ It has been questioned whether forcing an individual to provide a DNA sample is contrary to any constitutional limitations however, a recent Third Circuit decision has concluded that the legislation passes constitutional muster. ${ }^{2}$

With the DNA Fingerprint Act of $2005^{3}$ ("DNA Act"), Congress expanded the power of law enforcement by authorizing the collection of DNA samples from arrestees. ${ }^{4}$ To obtain a DNA sample from an individual, law enforcement essentially only needs to arrest that person. ${ }^{5}$

Obtaining DNA via arrest therefore does not necessarily require a warrant, giving great

\footnotetext{
* Anip Patel is a 2013 J.D. Candidate at Temple University's Beasley School of Law. He would like to thank his friends, family and professors for all of their support not only in writing this article but also throughout law school. He would like to dedicate this article in memory of his mother.

${ }^{1}$ Violence Against Women and Department Justice Reauthorization Act of 2005, Pub. L. No. 109-162, 119 Stat. 2960 (2006).

${ }^{2}$ United States v. Mitchell, 652 F.3d 387 (3d Cir. 2011), cert. denied, 132 S. Ct. 1741 (2012).

${ }^{3}$ Violence Against Women and Department Justice Reauthorization Act of 2005, supra note 1.

${ }^{4} I d$.

${ }^{5} I d$.
} 
discretion to law enforcement (especially considering that law enforcement is permitted to collect DNA samples from the arrestees after establishing probable cause). ${ }^{6}$ Furthermore, given that DNA sample collection is performed via a buccal swab or a blood extraction, all forms of DNA collection result in a minimal level of bodily intrusion. ${ }^{7}$ Under the federal law, once a DNA sample is collected, a DNA profile is created and uploaded onto the Combined DNA Index System ("CODIS"). ${ }^{8}$ Technically, the DNA profile consists of so-called "Junk DNA:" noncoding DNA, for which the scientists have yet to decipher its purpose. ${ }^{9}$ In order to go from a DNA sample (which contains genome traits) to a DNA profile (which does not contain genome traits), the laboratories, which receive the DNA sample, must locate the thirteen core genetic loci used in CODIS. ${ }^{10}$ Even with the extraction of this additional information, courts have not found a constitutional violation. ${ }^{11}$ Instead, courts have ruled that this type of collection is a search. ${ }^{12}$ Thus, the only true question is the reasonableness of those searches for arrestees.

\footnotetext{
${ }^{6}$ Mitchell, 652 F.3d at 412 ("DNA collection occurs only after it has been determined that there is probable cause to believe that the arrestee committed a crime.").

${ }^{7}$ See Memorandum from Att'y Gen. Eric H. Holder Jr., on DNA Sample Collection from Fed. Arrestees and Defendants for Asst. Att'y Gen., Criminal Division 2, 3 (Nov. 2010) ("The authorized method of DNA sample collection from non-convicts in the federal jurisdiction is by buccal (cheek) swab...The Probation Offices have collected DNA (in the form of blood samples) from convicted offenders"), available at http://www.justice.gov/ag/ag-memo-dna-collection111810.pdf [hereinafter Holder Memorandum].

842 U.S.C. $\$ 14135$ (2006 \& Supp. II 2008).

${ }^{9}$ Solomon Moore, In a Lab, an Ever-Growing Database of DNA Profiles, N.Y. TIMES, May 11, 2009, available at http://www.nytimes.com/2009/05/12/science/12quan.html.

${ }^{10}$ See Frequently Asked Questions (FAQs) on the CODIS Program and the National DNA Index System, FEDERAL BUREAU OF INVESTIGATION, http://www.fbi.gov/about-us/lab/codis/codis-and-ndis-fact-sheet (last visited Oct. 27, 2012) ("The DNA profile ... is stored in the database. For Forensic STR DNA analysis, the DNA profile consists of one or two alleles at the 13 CODIS core loci.").

${ }^{11}$ See Mitchell, 652 F.3d at 400-01 ("STRs are useful for identification not because of any genetic information but because they 'result[] in different numbers of copies of repeated sequences." (citing Henry T. Greely et al., Family Ties: The Use of DNA Offender Databases to Catch Offenders' Kin, 34 J.L. MED. \& ETHICS 248, 249 (2006))).

${ }^{12}$ See United States v. Sczubelek, 402 F.3d 175, 182 (3d Cir. 2005) ("Requiring Sczubelek to give a blood sample constitutes a Fourth Amendment search.”); Skinner v. Ry. Labor Execs. Ass'n, 489 U.S. 602, 616 (1989) (“[T]his physical intrusion, penetrating beneath the skin, infringes an expectation of privacy that society is prepared to recognize as reasonable.").
} 
In United States v. Mitchell, ${ }^{13}$ the Third Circuit addressed the reasonableness of DNA sampling of arrestees. The court held that DNA fingerprinting is akin to fingerprint collection in that the arrestees and the pretrial detainees have a diminished expectation of privacy in their identities; therefore, the collection of a DNA sample is reasonable and does not violate the Fourth Amendment. ${ }^{14}$ The court applied the "totality of circumstances" test and based its reasoning on case-law that dealt with the collection of DNA samples from convicted felons. ${ }^{15}$

The DNA Act presents an intriguing challenge for courts by introducing the question of whether the Fourth Amendment provides an arrested individual with a high enough expectation of privacy that would prevent law enforcement from obtaining a DNA sample without the intervention of a judicial magistrate. ${ }^{16}$ Courts have treated DNA fingerprinting as a natural technological progression from simple fingerprint analysis. ${ }^{17}$ However, courts should engage in a careful analysis before deciding that a technological progression of an already established procedure passes constitutional muster. They should consider all the safeguards and necessary precautions before finding that progression to be constitutional. For instance, in Kyllo v. United States, ${ }^{18}$ the Supreme Court held that thermal imaging of a home, showing the emanation of relative amounts of heat, is unconstitutional even though observing a home from the outside is an

\footnotetext{
${ }^{13}$ United States v. Mitchell, 652 F.3d 387 (3d Cir. 2011).

${ }^{14} I d$. at 413.

${ }^{15}$ Id. at 415-16.

${ }^{16}$ See People v. Buza, 129 Cal. Rptr. 3d 753, 783 (Cal. Ct. App. 2011) (“"[T]o the extent [the DNA Act] requires felony arrestees to submit a DNA sample ... without independent suspicion, a warrant or even a judicial or grand jury determination of probable cause, unreasonably intrudes on such arrestees' expectation of privacy and is invalid under the Fourth Amendment ...").

${ }^{17}$ See Johnson v. Ogershok, 4:02-CV-1525, 2004 WL 3622383, at *7 (M.D. Pa. Aug. 17, 2004) ("We find that the ability of law enforcement to now collect and keep DNA samples is simply a technological progression of photographs and fingerprints which have long been permitted to be kept for convicted persons in order to maintain a complete and more thorough database for identifying purposes.").

${ }^{18}$ Kyllo v. United States, 533 U.S. 27 (2001).
} 
established constitutional procedure. ${ }^{19}$ The distinguishing fact from Kyllo was that the thermal imaging observed an activity that was occurring inside a home, which is private. ${ }^{20}$ DNA sampling could be a greater intrusion into a citizen's privacy than fingerprint collection because it has the capability of revealing far more information than fingerprints. ${ }^{21}$ Consequently, “[f]ingerprinting presents no [substantial] threat to privacy" as compared with DNA fingerprinting. ${ }^{22}$ However, the analogous "distinguishing fact" does not exist for DNA samplings, the Fourth Amendment should not be used as a blanket protection, and DNA sampling of arrestees, with the proper safeguards, should not be deemed a violation of the Fourth Amendment. ${ }^{23}$

In the past, courts have provided greater protections to individuals from constitutional violations, especially in the Fourth Amendment cases. For instance, in Schmerber v. State of California, ${ }^{24}$ Justice Brennan stated that " $[\mathrm{t}]$ he interests in human dignity and privacy which the Fourth Amendment protects forbid [intrusions beyond the body's surface] on the mere chance that desired evidence might be obtained." ${ }^{, 25}$ However, with the improvements in technology, the courts' interpretation of the Constitution has moved further from Justice Brennan's belief and treaded towards an interpretation that makes the Constitution seem archaic, and incapable of

\footnotetext{
${ }^{19} I d$. at 40. See also United States v. Karo, 468 U.S. 705, 731 (1984) ("When a person's property is concealed from public view ... then the fact of his possession is private and the subject of Fourth Amendment protection.").

${ }^{20}$ Kyllo, 533 U.S. at 40 ("Where, as here, the Government uses a device that is not in general public use, to explore details of the home that would previously have been unknowable without physical intrusion, the surveillance is a 'search' and is presumptively unreasonable without a warrant.").

${ }^{21}$ See Haskell v. Harris, 669 F.3d 1049, 1079 (9th Cir. 2012) (Fletcher, J., dissenting) (“Even with today’s technology ... junk DNA reveals more information than a fingerprint.”).

${ }^{22}$ Buza, 129 Cal. Rptr. 3d at 769.

${ }^{23}$ See United States v. Pool, 645 F. Supp. 2d 903, 912 (E.D. Cal. 2009) ("The Attorney General regulations describe that the DNA will be taken during the identification process after the arrest. ... [T] he statute also contains privacy protections and imposes criminal and financial penalties for improper use of DNA samples.").

${ }^{24}$ Schmerber v. California, 384 U.S. 757 (1966).

${ }^{25} I d$. at 770 .
} 
protecting against intrusions into privacy as a result of modern technological advances. ${ }^{26}$ In order for the Constitution (more specifically, the Fourth Amendment) to survive technological advances, courts must implement proper safeguards to protect against methods that could violate the Fourth Amendment standards. The technological progression of an established procedure does not necessarily mean that such a progression is constitutional.

Part I of this Comment will describe the historical development of DNA fingerprinting. This section will explain the emergence of the use of DNA extraction for probationers and convicted felons and examine case-law to determine an arrestee's expectation of privacy. It will conclude by examining the applicable Fourth Amendment tests. Part II will discuss recent relevant case-law that examines the reasonableness of DNA fingerprints. This section will also explore the significance of "Junk DNA," and the treatment of abandoned DNA. Part III will explain why I believe that DNA fingerprinting, with the proper safeguards, is constitutional under the Fourth Amendment. It will determine the proper Fourth Amendment test, establish how that test relates to DNA sampling, compare fingerprints to DNA sampling, and analyze abandoned DNA.

\section{BACKGROUND}

Consistent with the advances in technology, law enforcement has been implementing increasingly sophisticated equipment to catch criminals. ${ }^{27}$ Although these methods have

\footnotetext{
${ }^{26}$ See Skinner v. Ry. Labor Execs. Ass'n, 489 U.S. 602, 616 (1989) ("[I]t is obvious that this physical intrusion, penetrating beneath the skin, infringes an expectation of privacy that society is prepared to recognized as reasonable.").

${ }^{27}$ See Ellen Messmer, FBI Turns up Faster, More Accurate Fingerprint Identification System, COMPUTERWORLD (Mar. 9, 2011), http://computerworld.co.nz/news.nsf/security/fbi-turns-up-faster-more-accurate-fingerprintidentification-system ("The FBI . . . said it's made a long-awaited switch from its Automated Fingerprint Identification System (AFIS) to an upgraded, faster one the FBI calls Advanced Fingerprint Information Technology
} 
significantly aided law enforcement officials in apprehending offenders, the constitutionality of such methods has been a cause of concern. DNA fingerprinting is one such procedure where courts have struggled to determine its constitutionality. ${ }^{28}$ The history of DNA sampling demonstrates the law's formulation and its expansion into the collection of samples from arrestees.

\section{A. Examination of the DNA Extraction Statutes}

In 1984, Alex Jeffreys created the idea of DNA fingerprinting as a method of identifying individuals based on their DNA. ${ }^{29}$ The 1994 Violent Crime Control and Law Enforcement Act resulted from this basic development, establishing CODIS by making "funds available. . . to carry out all or a substantial part of a program or project intended to develop or improve the capability to analyze [DNA] in a forensic laboratory. ${ }^{\prime 30}$ Six years later, Congress enacted the DNA Analysis Backlog Elimination Act of 2000 ("DNA Analysis Act") to enable the Bureau of Prisons Director to collect a DNA sample from every convicted prisoner (of a qualifying federal offense).$^{31}$ The DNA Analysis Act focused on individuals convicted of certain federal crimes, along with those who were incarcerated, paroled, and on probation or supervised release. ${ }^{32}$

(AFIT).”); Kim Zetter, Battle Brews Over FBI’s Warrantless GPS Tracking, WIRED (May 9, 2011, 7:00 AM), http://www.wired.com/threatlevel/2011/05/gps/ ("Rumors had been swirling among activists that the FBI might be using GPS to track them ...").

${ }^{28}$ Compare United States v. Mitchell, 652 F.3d 387 (3d Cir. 2011) (holding that collection of DNA samples from arrestees is not a violation of the Fourth Amendment) with People v. Buza, 129 Cal. Rptr. 3 d 753 (Cal. Ct. App. 2011) (holding that DNA sample collection without "independent suspicion, warrant or judicial or grand jury determination of probable cause" violates an arrestee's Fourth Amendment rights).

${ }^{29}$ DNA's Twists of History, U.S. NEWS \& WORLD REPORT (Feb. 16, 2003), http://www.usnews.com/usnews/culture/articles/030224/24dna.b.htm.

${ }^{30} 42$ U.S.C. $\$ 3796 \mathrm{kk}(2006)$.

${ }^{31} 42$ U.S.C. $\$ 14135 \mathrm{a}(2006)$.

${ }^{32}$ United States v. Kincade, 379 F.3d 813, 816-17 (9th Cir. 2004). 
In 2004, the DNA Analysis Act was expanded to qualify all felonies for DNA sampling. ${ }^{33}$ The expansion continued, and by 2006, the DNA Analysis Act allowed the "Attorney General . . . [to] collect DNA samples from individuals who are arrested, facing charges, or convicted or from non-United States persons who are detained under the authority of the United States."34 Currently, all fifty states and the federal government have enacted laws requiring DNA collection from an offender. ${ }^{35}$ Moreover, twenty-five states and the federal government have passed legislation requiring the collection of a DNA sample upon arrest for certain felonies. ${ }^{36}$

After collecting the DNA sample, DNA profiles are generated. The DNA profiles are used for identification purposes, much like fingerprints and mug-shots. ${ }^{37}$ The FBI creates the DNA profile by using "short tandem repeat (STR) technology to analyze repeating sequences found at thirteen specific regions, or loci, on an individual's DNA., ${ }^{38}$ Profiles are created by using "junk DNA" — "DNA that differs from one individual to the next and thus can be used for purposes of identification but which was 'purposely selected because [it is] not associated with any known physical or medical characteristics' and 'do[es] not control or influence the expression of any trait.",39 In order to maintain confidentiality, "the profiles contain only 'an agency identifier for the agencies submitting the DNA profile; the specimen identification

\footnotetext{
${ }^{33}$ United States v. Kriesel, 508 F.3d 941, 942 (9th Cir. 2007).

3442 U.S.C. $\$ 14135(a)(1)(A)$ (2006 \& Supp. II 2008).

${ }^{35}$ Fact Sheet: Legislation to Advance Justice Through DNA Technology, DEPT. OF JUSTICE, http://www.justice.gov/ag/dnalegislation.htm ("All 50 states and the federal government have laws requiring that DNA be collected from some categories of offenders.”) (last visited November 18, 2012).

${ }^{36}$ Protecting the Public with Arrestee DNA Database Legislation, DNARESOURCE.COM http://www.dnaresource.com/documents/Privacytalkingpoints.pdf (last visited Oct. 27, 2012).

${ }^{37}$ Boroian v. Mueller, 616 F.3d 60, 65 (1st Cir. 2010) ("DNA profiles currently function as identification records not unlike fingerprints, photographs, or social security numbers.”).

${ }^{38}$ Id. at 65-66.

${ }^{39}$ United States v. Weikert, 504 F.3d 1, 3-4 (1st Cir. 2007) (quoting H.R.REP. No. 106-900(I), at 27 (2000)).
} 
number; the DNA profile; and the name of the DNA personnel associated with the DNA

analysis." "40 After the profile is created, it is entered into CODIS.

Safeguards in the DNA Analysis Act prevent the improper use of DNA samples. ${ }^{41}$ The DNA Analysis Act states that "[a] person who knowingly discloses a sample or result ... to any person not authorized to receive it, or obtains or uses, without authorization ... shall be fined not more than $\$ 250,000$, or imprisoned for a period of not more than one year." ${ }^{42}$ Furthermore, the:

Crime Control Act limits disclosure "to criminal justice agencies for law enforcement identification purposes;" "in judicial proceedings, if otherwise admissible;" "for criminal defense purposes, to a defendant who shall have access to samples or analyses performed in connection with the case in which such defendant is charged;" and, "if personally identifiable information is removed, for a population statistics database, for identification research and protocol development purposes, or for quality control purposes."43

\section{B. What is an Arrestee's Expectation of Privacy}

\section{Schmerber v. State of California}

In Schmerber v. California, ${ }^{44}$ the Supreme Court addressed whether an arrestee's Fourth Amendment rights were violated when law enforcement took his blood sample against his will. ${ }^{45}$ Police arrested the defendant at a hospital for driving while intoxicated, and also directed a physician to withdraw a blood sample from the defendant's body. ${ }^{46}$ Even though the defendant objected, a physician took a blood sample and an analysis of the "sample revealed a percent by

\footnotetext{
${ }^{40} I d$. at 4.

${ }^{41}$ United States v. Mitchell, 652 F.3d 387, 399 (3d Cir. 2011) (“[The DNA Analysis Act] . . includes a number of safeguards to prevent the improper use of DNA samples.").

4242 U.S.C. $\$ 14135 \mathrm{e}(\mathrm{c})(2006)$.

4342 U.S.C. $\$ 14133($ b)(2) (2006).

${ }^{44}$ Schmerber v. California, 384 U.S. 757 (1966).

${ }^{45} \mathrm{Id}$. at $766-67$.

${ }^{46} I d$. at 758 .
} 
weight of alcohol in his blood at the time of the offense which indicated intoxication." ${ }^{\text {"4 }}$ The defendant argued that the withdrawal of his blood constituted an unreasonable search and seizure in violation of his Fourth Amendment rights. ${ }^{48}$ Ultimately, the Supreme Court held "that the Constitution does not forbid the States minor intrusions into an individual's body under stringently limited conditions [and this decision] in no way indicates that [the Court] permits more substantial intrusions, or intrusions under other conditions."49

The Court acknowledged that the Fourth Amendment was designed to protect an individual's privacy and dignity by preventing unwarranted State intrusion. ${ }^{50}$ However, the Court noted that "the Fourth Amendment's proper function is to constrain, not against all intrusions as such, but against intrusions which are not justified in the circumstances, or which are made in an improper manner." were justified in requiring the defendant to provide a blood test and whether the taking of his blood was reasonable. $^{52}$

The Court recognized that the officer was reasonably confronted with an emergency because the delay that would have resulted from acquiring a warrant could have destroyed potential evidence. ${ }^{53}$ Conversely, the Court noted that the Fourth Amendment protects interests in human dignity and privacy, and the possibility that evidence may be obtained (or destroyed) is

${ }^{47} I d$. at 759.

${ }^{48} I d$.

${ }^{49} I d$. at 772.

${ }^{50}$ Schmerber v. California, 384 U.S. 757, 767 (1966) ("The overriding function of the Fourth Amendment is to protect personal privacy and dignity against unwarranted intrusion by the State.").

${ }^{51} I d$. at 768 .

${ }^{52}$ Id. (the Court considered "whether the police were justified in requiring petitioner to submit to the blood test, and whether the means and procedures employed in taking his blood respected relevant Fourth Amendment standards of reasonableness.").

${ }^{53} I d$. at 770 ("[The officer] might reasonably have believed that he was confronted with an emergency, in which the delay necessary to obtain a warrant, under the circumstances, threatened 'the destruction of evidence.'”). 
not a sufficient justification for allowing physical intrusions into an individual's body. ${ }^{54}$ Thus, in order to narrow the types of intrusions that contravene human dignity and privacy, the Court stated that absent "a clear indication that in fact ... evidence will be found, these fundamental human interests require law officers to suffer the risk that such evidence may disappear unless there is an immediate search."55 To determine if this narrow interpretation applied to this case, the Court had to ascertain whether the officer could draw inferences or needed to acquire a warrant before administering the blood test. ${ }^{56}$

Search warrants are typically required to search an individual's home so, the court ruled that unless an emergency existed, intrusions into an individual's body required a search warrant. ${ }^{57}$ The Court held, "[t]he requirement that a warrant be obtained is a requirement that inferences to support the search 'be drawn by a neutral and detached magistrate instead of being judged by the officer engaged in the often competitive enterprise of ferreting out crime.",58 A search warrant involves a judge who is capable of providing an opinion based on the objective facts presented and not on any subjective beliefs or inclinations stemming from the arrestee or the situation. ${ }^{59}$

Although the Court stressed the importance and necessity of a search warrant, it concluded that the circumstances did not require the officer to obtain a warrant in this case because the individual's blood alcohol level was diminishing and there was an increased

\footnotetext{
${ }^{54} I d$. at 769-70 ("The interests in human dignity and privacy which the Fourth Amendment protects forbid any such intrusions on the mere chance that desired evidence might be obtained.").

${ }^{55} I d$. at 770 (the Court considered "whether the arresting officer was permitted to draw [. . .] inferences himself, or was required instead to procure a warrant before proceeding with the test.").

${ }^{56}$ Schmerber v. United States, 384 U.S. 770 (1966).

${ }^{57} I d$. ("Search warrants are ordinarily required for searches of dwellings, and absent an emergency, no less could be required where intrusions into the human body are concerned.").

${ }^{58}$ Id. (quoting Johnson v. United States, 333 U.S. 10, 13-14 (1948)).

${ }^{59}$ See id. ("The importance of informed, detached and deliberate determinations of the issue whether or not to invade another's body in search of evidence of guilt is indisputable and great.").
} 
possibility that evidence would be lost. ${ }^{60}$ Consequently, the Court held that based on these special facts, "the attempt to secure evidence of blood-alcohol content in this case was an appropriate incident to petitioner's arrest." ${ }^{\prime 61}$

\section{Winston v. Lee}

Almost twenty years after Schmerber, the Supreme Court ruled on another case involving the Fourth Amendment rights of an arrestee in Winston v. Lee. ${ }^{62}$ In Winston, the question was whether compelling a surgical intrusion against an individual's will implicates a reasonable expectation of privacy rendering the surgical intrusion unreasonable, even if evidence is produced by the search. ${ }^{63}$ The Court determined that " $[\mathrm{t}]$ he reasonableness of surgical intrusions beneath the skin depends on a case-by-case approach, in which the individual's interests in privacy and security are weighed against society's interests in conducting the procedure to obtain evidence for fairly determining guilt or innocence."64

Accordingly, the Court turned to Schmerber's consideration of other factors in determining reasonableness, such as the threat to the individual's health, the intrusion upon the individual's dignity, and the community's interests in ensuring that the correct individuals were held accountable for their crimes. ${ }^{65}$ The Court emphasized that Schmerber "cautioned: '[t]hat [the Court's holding] that the Constitution does not forbid the States['] minor intrusions into an individual's body under stringently limited conditions in no way indicates that it permits more

\footnotetext{
${ }^{60} I d$. at 770-71 ("[T] $]$ he percentage of alcohol in the blood begins to diminish shortly after drinking stops . . . [and therefore] there was no time to seek out a magistrate and secure a warrant.").

${ }^{61} I d$. at 770.

${ }^{62}$ Winston v. Lee, 470 U.S. 753 (1985).

${ }^{63} \mathrm{Id}$. at $753-54$.

${ }^{64} I d$. at 754.

${ }^{65}$ Id. ("[The Schmerber Court considered] ... the extent to which the procedure may threaten the individual's safety or health, the extent of intrusion upon the individual's dignity interests in personal privacy and bodily integrity, and the community's interest in fairly and accurately determining guilt or innocence.”).
} 
substantial intrusions, or intrusions under other conditions." "66 Thus, the Court in Winston held that the surgical intrusion was the type of bodily search that Schmerber had cautioned against so, permitting such a procedure would violate the individual's Fourth Amendment right. ${ }^{67}$

To support its decision, the Court assessed the Fourth Amendment and expectation of privacy. Additionally, even though Schmerber did not require a warrant (because it was based on exigent circumstances), the Winston court determined that Schmerber provided the proper analytical framework for situations where a court must weigh law enforcement's need for evidence against the individual's interest in privacy. ${ }^{68}$ Expectation of privacy is considered one of society's most valuable rights because it allows individuals to go about their business without having to worry about anyone (especially law enforcement) invading their personal space or violating their right to be left alone. ${ }^{69}$ The scope of the Fourth Amendment was found to “generally [protect] the 'security' of 'persons, houses, papers, and effects' against official intrusions up to the point where the community's need for evidence surmounts a specified standard, ordinarily "probable cause.",70 However, the Court conceded that "[b]eyond this point, it is ordinarily justifiable for the community to demand that the individual give up some part of his interest in privacy and security to advance the community's vital interests in law enforcement; such a search is generally 'reasonable' in the Amendment's terms." ${ }^{\text {71 }}$ In the instant case, the Court held that a compelled surgical intrusion for evidence was still an intrusion of an

\footnotetext{
${ }^{66} I d$. at 755 .

${ }^{67}$ Id. ("'Surgical intrusion is] . . a an example of the 'more substantial intrusion' cautioned against in Schmerber, and ... that to permit the procedure would violate respondent's right to be secure in his person guaranteed by the Fourth Amendment.").

${ }^{68}$ Winston v. Lee, 470 U.S. 753, 760 (1985) (“' [Schmerber] . . provides the appropriate framework of analysis for [cases where the need for evidence is weighed against an individual's privacy interest].”).

${ }^{69}$ See id. at 758 ("[Expectation of privacy is an] . . . individual's legitimate expectation[] that in certain places and at certain times he has 'the right to be let alone [and is considered] the most comprehensive of rights and the right most valued by civilized men."') (quoting Olmstead v. United States, 277 U.S. 438, 478 (1928) (Brandeis, J., dissenting)). ${ }^{70} I d$. at 759 .

${ }^{71} I d$.
} 
individual's expectation of privacy, and consequently, such a search was held to be unreasonable regardless of the potential to produce evidence. ${ }^{72}$

To arrive at this conclusion, the Court examined a number of factors used by the Schmerber Court to determine reasonableness. The effect of the intrusion on the individual's health probably became the most crucial factor for the Court. ${ }^{73}$ "Notwithstanding the existence of probable cause, a search for evidence of a crime may be unjustifiable if it endangers the life or health of the suspect." ${ }^{, 74}$ The other factor is the extent to which surgery intrudes upon the individual's dignitary interests in personal privacy and bodily integrity. ${ }^{75}$ Given that the Court determined that the Commonwealth had probable cause for the search, it focused on balancing the extent of the intrusion on the individual's privacy interests against the State's interests. ${ }^{76}$

In applying the facts of this case, the Court noted that general anesthesia surgery, with the patient's consent, is not a demeaning or intrusive procedure, but the "kind of surgery [in this case] involves a virtually total divestment of respondent's ordinary control over surgical probing beneath his skin."77 Additionally, in examining the State's need for the evidence, the Court stated that the Commonwealth already had substantial evidence, which disclosed the origin of the bullet, thus diminishing the need to compel the defendant to undergo surgery. ${ }^{78}$

Ultimately, the Court held that Fourth Amendment protections are less stringent when there is a lower expectation of privacy or where there is only a minimal intrusion of privacy. ${ }^{79}$

\footnotetext{
${ }^{72} I d$. ("[Surgical intrusion] . . implicates expectations of privacy and security of such magnitude that the intrusion may be 'unreasonable' even if likely to produce evidence of a crime.").

${ }^{73} \mathrm{Id}$. at 761 ("A crucial factor in analyzing the magnitude of the intrusion ... is the extent to which the procedure may threaten the safety of health of the individual.").

${ }^{74}$ Winston v. Lee, 470 U.S. 753, 761 (1985).

${ }^{75} \mathrm{Id}$.

${ }^{76} I d$. at 763 .

${ }^{77} I d$. at 764 .

${ }_{79}^{78}$ Id. at 765-66.

${ }^{79} \mathrm{Id}$.
} 
However, all searches must still be reasonable and if the State tries to intrude a significantly heightened privacy interest, then the State must provide a substantial justification to classify the search as reasonable. ${ }^{80}$

\section{Applicable Fourth Amendment Tests}

The Framers created the Fourth Amendment to ensure that " $[\mathrm{t}]$ he right of the people to be secure in their persons, houses, papers, and effects, against unreasonable searches and seizures, [is] not violated" unless a warrant is issued based on probable cause. ${ }^{81}$ After the Supreme Court's decision in Skinner v. Railway Labor Executives' Ass' $n,{ }^{82}$ there was no question as to whether DNA extraction was subject to the Fourth Amendment analysis because the Court "has long recognized that a compelled intrusion into the body for blood to be tested ... and the ensuing chemical analysis constitute searches." ${ }^{\prime 83}$ Thus, the only issue to be resolved is whether the DNA sampling of arrestees is reasonable.

In order to determine whether a search is reasonable, either the "special needs test" or the "totality of the circumstances test" must be applied. Courts were split over which one of these two tests governed cases that challenged the reasonableness of DNA extraction statutes. ${ }^{84}$ The special needs doctrine was applied in "cases [that] involve[d] searches conducted for important non-law enforcement purposes in contexts where adherence to the warrant-and-probable cause requirement would be impracticable." 85 However, only a minority of circuits implemented the

\footnotetext{
${ }^{80}$ Winston v. Lee, 470 U.S. 753, 767 (1985).

${ }^{81}$ U.S. CONST. amend. IV.

82489 U.S. 602 (1989).

${ }^{83}$ Skinner v. Ry. Labor Execs. Ass'n, 489 U.S. 602, 603 (1989).

${ }^{84}$ Compare Indianapolis v. Edmond, 531 U.S. 32, 47 (2000) (applying the special needs test), with United States v. Knights, 534 U.S. 112, 122 (2001) (applying the totality of circumstances test).

${ }^{85}$ United States v. Kincade, 379 F.3d 813, 823 (9th Cir. 2004) (emphasis added); see also Griffin v. Wisconsin, 483

U.S. 868, 873 (1987) (permitting exceptions when "special needs, beyond the normal need for law enforcement,
} 
special needs test when determining reasonableness for DNA extraction. ${ }^{86}$ Furthermore, the Supreme Court has never held that a probationer or parolee should be subjected to a full search "at the whim of any law enforcement officer he happens to encounter," regardless of whether there is a reason to suspect that individual of wrongdoing. ${ }^{87}$

On the other hand, a majority of circuit courts have used the totality of the circumstances test for DNA extraction statutes. ${ }^{88}$ Under this approach, reasonableness is determined by comparing the degree of intrusion into the individual's privacy with the degree of intrusion needed to promote a legitimate governmental interest. ${ }^{89}$ Courts consider numerous factors when balancing the interests of an individual's privacy with that of the government's interest in DNA collection. Generally, the circuits have examined the following: the extent of intrusion required for collection, the expectation of privacy enjoyed by the individual, the need for DNA collection as a legitimate governmental interest, the safeguards implemented, possibility of expungement, make the warrant and probable-cause requirement impracticable.”) (quoting New Jersey v. T.L.O., 469 U.S. 325, $351(1985))$.

${ }^{86}$ See Roe v. Marcotte, 193 F.3d 72, 79 (2d Cir. 1999) (“[C]onclude that a reasoned interpretation of the "special needs' doctrine supports the constitutionality of the DNA statute."); Green v. Berge, 354 F.3d 675, 679 (7th Cir. 2004) (holding that the Wisconsin DNA collection statute survives the constitutional attack under the special needs doctrine).

${ }^{87}$ Samson v. California, 547 U.S. 843, 859 (2006).

${ }^{88}$ See United States v. Weikert, 504 F.3d 1, 10 (1st Cir. 2007) ("[T] than the special needs analysis, is appropriate."); United States v. Sczubelek, 402 F.3d 175, 184 (3d Cir. 2005) (" $[\mathrm{U}]$ nder the totality of circumstances, the taking of a DNA sample from an individual on supervised release is not an unreasonable search."); Jones v. Murray, 962 F.2d 302, 305 (4th Cir. 1992) (“[T]aking of blood samples under these circumstances is reasonable."); Groceman v. U.S. Dep't of Justice, 354 F.3d 411, 413 (5th Cir. 2004) (" $[\mathrm{C}]$ ollections are reasonable in light of an inmate's diminished privacy rights, the minimal intrusion involved, and the legitimate government interest ...."); Wilson v. Collins, 517 F.3d 421, 427 (6th Cir. 2008) ("Ohio DNA statute ... is properly evaluated under the totality-of-the-circumstances test."); United States v. Kraklio, 451 F.3d 922, 92425 (8th Cir. 2006) (" $[\mathrm{H}]$ old, based on the totality of the circumstances, the collection of DNA under the DNA Act . . . does not constitute an unreasonable search and seizure ....”); United States v. Kriesel, 508 F.3d 941, 946 (9th Cir. 2007) ("[C]ontinue to ground our analysis in the totality of circumstances test"); Padgett v. Donald, 401 F.3d 1273, 1280 (11th Cir. 2005) ("[A]ddress whether the statute is reasonable under a totality of the circumstances analysis."); Johnson v. Quander, 440 F.3d 489, 496 (D.C. Cir. 2006) (joining the "unanimous body of authority" by concluding DNA sample collection as reasonable).

${ }^{89}$ Knights, 534 U.S. at 112-13. 
and the contribution to solving past crimes. ${ }^{90}$ Under this test, courts found minimal intrusion by DNA tests, and also determined that convicted felons and those on supervised release "ha[d] a reduced right to privacy - and in particular to privacy of identity[.] . . Individuals on supervised release cannot reasonably expect to keep information bearing on their physical identify from government records." 91

\section{Discussion}

\section{A. United States v. Mitchell}

The revolutionary Third Circuit case of Mitchell dealt with whether, after the indictment, arrest, and detention, it is constitutional under the Fourth Amendment for the government to collect a DNA sample pursuant to the DNA Analysis Act. ${ }^{92}$ In Mitchell, the defendant was indicted on one count of attempted possession with the intent to distribute cocaine. ${ }^{93}$ The District Court's analysis, as well as the majority and the dissenting opinions from the Third Circuit, are relevant in understanding the arguments presented for and against DNA Sampling.

\section{The District Court's Reasoning}

The District Court applied the totality of the circumstances test and held that "'Mitchell $\mathrm{ha}[\mathrm{d}]$ a diminished expectation of privacy in his identity' and thus may be subjected to routine booking procedures such as fingerprinting." 94 The District Court did not equate fingerprinting identification to DNA profiling because a DNA sample contains "complex, comprehensive,

\footnotetext{
${ }^{90}$ United States v. Mitchell, 652 F.3d 387, 403-05 (3d Cir. 2011).

${ }^{91}$ Id. at 404 (quoting Sczubelek, 402 F.3d at 184-85); see Padgett, 401 F.3d at 1280 (finding that a prisoner has a reduced expectation of privacy).

${ }_{92}$ Mitchell, 652 F.3d at 389.

${ }^{93} \mathrm{Id}$. at 390.

${ }^{94} I d$. (quoting United States v. Mitchell, 681 F. Supp. 2d 597, 608 (W.D. Pa. 2009)).
} 
[and] inherently private information." ${ }^{.95}$ More than "a mere progression" from fingerprinting and photographing an arrestee, "[t]he extraction of DNA ... represents a quantum leap that is entirely unnecessary for identification purposes. ${ }^{, 96}$ Furthermore, the District Court compared the degree of intrusion that DNA collection brought upon an individual's privacy with the extent that the government's interests were promoted. ${ }^{97}$ Ultimately, the District Court found that the government's interests did not outweigh the defendant's interests because there was no compelling reason to take a DNA sample for identification purposes and therefore, taking the defendant's DNA sample was a violation of the Fourth Amendment. ${ }^{98}$

\section{The Third Circuit's Analysis}

Contrary to the district court's decision, the Third Circuit applied the totality of the circumstances test and held that the collection of a DNA sample constituted a reasonable search under the Fourth Amendment. ${ }^{99}$ In balancing the interests of the government and the defendant, the Third Circuit stated that identifying arrestees was the most compelling interest for the government. ${ }^{100}$ The Third Circuit found that DNA sampling and matching worked to a greater precision than fingerprinting, and therefore, DNA profiles were better for identifying individuals than fingerprints. ${ }^{101}$ The Third Circuit acknowledged that possible misuses of DNA samples is a serious concern but ruled that the "hypothetical possibilities are unsupported by the record before

\footnotetext{
${ }^{95} \mathrm{Id}$. at 412 (internal citations omitted).

${ }^{96} \mathrm{Id}$. at 412 (internal citations omitted).

${ }^{97}$ Id. at 390 (quoting Samson v. California, 547 U.S. 843, 848 (2006)).

${ }^{98}$ United States v. Mitchell, 652 F.3d 387, 391 (3d Cir. 2011).

${ }^{99} I d$. at $415-16$.

${ }^{100} I d$. at 413 ("Most compelling [of the governmental interests] is the Government's strong interest in identifying arrestees.").

${ }^{101} I d$. at 413 ("Given 'the potentially greater precision of DNA sampling and matching methods,' DNA profiling serves this interest [of identifying individuals] better than fingerprinting.") (citing United States v. Sczubelek, 402 F.3d 175, 186 (3d Cir. 2005)).
} 
[the court]" and consequently, the court did not factor hypothetical concerns into its totality of circumstances analysis. ${ }^{102}$ However, the Third Circuit conceded that if "junk DNA" became valuable, then it would be appropriate to reconsider its Fourth Amendment analysis. ${ }^{103}$ Lastly, the Third Circuit analogized DNA sampling to fingerprinting: DNA profiles served as genetic fingerprints, they were used solely for identification, and information from DNA samples did not intrude arrestees' and pretrial detainees' privacy interests due to their diminished expectation of privacy. ${ }^{104}$

Conversely, the dissent in Mitchell held that requiring all arrestees to be swabbed violated the principles of the Fourth Amendment. ${ }^{105}$ The dissent did not find that the government's intent to use an arrestee's DNA for the purposes of solving other crimes was a compelling interest. $^{106}$ The dissent disagreed with the majority's holding because it essentially held that if an individual was wrongfully arrested, the government would still have the right to collect a DNA sample, create a DNA profile, and upload that profile onto CODIS. ${ }^{107}$ The dissent was uncomfortable with the idea that an arrestee could not protest or prevent the taking of his DNA, and would have to obtain a certified final court order that acquitted the arrestee, and then supply it to the government. ${ }^{108}$ Ultimately, the dissent explained that "although his DNA profile will be expunged from CODIS, the Government will retain his DNA sample indefinitely."109

\footnotetext{
${ }^{102} I d$. at 408 .

${ }^{103} \mathrm{Id}$.

${ }^{104}$ United States v. Mitchell, 652 F.3d 387, 412 (3d Cir. 2011) ("DNA profiles developed pursuant to the DNA Act function as 'genetic fingerprints' used only for identification purposes, [and] arrestees and pretrial detainees have reduced privacy interests in the information derived from a DNA sample.").

${ }^{105} I d$. at 431 (Rendell, J., dissenting) ("[B]lanket mandate [that all arrestees are to be swabbed] contradicts basic and essential Fourth Amendment principles.").

${ }^{106} I d$. at 416 (Rendell, J., dissenting).

${ }^{107} I d$. at 420 (Rendell, J., dissenting) (“[The Majority's holding] . . . mean[t] that if a person is arrested for a federal crime in a case of mistaken identity (an all-too-common occurrence), the Government has the automatic right to sample the arrestee's DNA, to analyze it, and to include a profile derived from the DNA sample in CODIS.").

${ }^{108}$ Id. (quoting 42 U.S.C. $§ 14132(\mathrm{~d})(1)(\mathrm{A})(\mathrm{ii})(2006)$ ).

${ }^{109} \mathrm{Id}$.
} 
The dissent also determined that there was a difference between being an arrestee and a pretrial detainee (like Mitchell), and a convict, and therefore, the factors considered under the totality of the circumstances test would also be different. ${ }^{110}$ The dissent considered the arrestees' expectation of privacy and the pretrial detainees' expectation of privacy to be much greater than that of a convict, thereby reducing the government's interest in collecting and analyzing DNA samples. ${ }^{111}$ In terms of expectation of privacy, the dissent distinguished convicts from arrestees/pretrial detainees:

Convicts ... have been found guilty beyond a reasonable doubt, not just accused of a crime. The conviction carries with it a permanent change in the person's status from ordinary citizen to "lawfully adjudicated criminal [ ] . . . whose proven conduct substantially heightens the government's interest in monitoring" him and "quite properly carries lasting consequences." ... Because they have not been adjudged guilty of any crime or suffered any corresponding permanent change in their status, arrestees and pretrial detainees necessarily retain a greater expectation of privacy than convicts do. ${ }^{112}$

With regard to the compelling governmental interest in analyzing the DNA, the dissent stated that unlike in the matter of convicted individuals, the government could not justify the collection and analysis of DNA by assuming that all individuals whose DNA was collected would be more likely than others to commit crimes in the future. ${ }^{113}$

The dissent did not find persuasive the idea that DNA profiling is the same as fingerprinting. Unlike DNA, the science behind fingerprints and mug shots has not evolved to the point where each could be used for purposes other than identification. ${ }^{114}$ The dissent pointed out that the collection of DNA required obtaining evidence that is found below the body's

\footnotetext{
${ }^{110}$ United States v. Mitchell, 652 F.3d 387, 421 (3d Cir. 2011).

${ }^{111} I d$.

${ }^{112}$ Id. (quoting United States v. Kincade, 379 F.3d 813, 836 (9th Cir. 2004)).

${ }^{113}$ Id. at 422 ("[T] he Government may not assume that the subjects of the DNA collection are more likely to commit future crimes to justify the collection and analysis of their DNA.").

${ }^{114} I d$. at 425 .
} 
surface, which is out of the public view. ${ }^{115}$ The dissent noted that photographs and fingerprints are primarily used to identify suspects, and to ensure that the arrested individual is in fact the person that law enforcement believes to have in custody (thus preventing a case for mistaken identity), but in this case, DNA was primarily used to solve crimes, and not for identification purposes. ${ }^{116}$ Ultimately, the dissent pointed to the Supreme Court's historical recognition that “generalized interests in 'law enforcement' a[re] a particularly suspect type of government interest for Fourth Amendment purposes, and [the Court] has specifically held invalid other suspicionless search programs that are designed to 'uncover evidence of ordinary criminal wrongdoing' by the targets of the search."117

\section{B. People v. Buza}

In People v. Buza, ${ }^{118}$ the California Appeals court dealt with a California statute that required felony-arrestees to submit a DNA sample, even if there was no "independent suspicion, a warrant or even a judicial or grand jury determination of probable cause. ..." The DNA sample would then be added to the state and federal DNA database. ${ }^{119}$ The California Appeals court found that the statute violated the Fourth Amendment because an arrestee's expectation of

\footnotetext{
${ }^{115} I d$.

${ }^{116}$ United States v. Mitchell, 652 F.3d 387, 425 (3d Cir. 2011) ("In the case of photographs and fingerprints, the Government's primary interest is to 'identify' suspects in the traditional sense, i.e., to 'ensure[ ] that the person who has been arrested is in fact the person law enforcement agents believe they have in custody.' But with respect to DNA, the Government's primary objective is to solve crimes.") (quoting United States v. Olivares-Rangel, 458 F.3d 1104, 1113 (10th Cir. 2006)).

${ }^{117}$ Id. at 428 (quoting Indianapolis v. Edmond, 531 U.S. 32, 42 (2000)).

${ }^{118}$ People v. Buza, 129 Cal. Rptr. 3d 753 (Cal. Ct. App. 2011) (review granted, opinion superseded) (as of Oct. 10, 2012, the California Supreme Court has not reviewed the case).

${ }^{119}$ Id. at 783 .
} 
privacy was unreasonably disturbed. ${ }^{120}$ In arriving at this conclusion, the court applied the totality of the circumstances test. ${ }^{121}$

The court first balanced the individual's privacy rights against the governmental interests, by initially focusing on the convicted felons' interests followed by the interests of the arrestees and the government. ${ }^{122}$ The court noted that "[c]onvicted offenders are subject to 'a broad range of [restrictions] that might infringe constitutional rights in free society' and have 'severely constricted expectations of privacy relative to the general citizenry." "123 Additionally, the government has a strong interest in identifying and prosecuting offenders, promoting rehabilitation, and protecting the community. ${ }^{124}$ The court then shifted its focus to individuals' status prior to conviction and pointed to the Friedman court, which noted that:

[S] uspicionless searches of pretrial detainees had not previously been upheld for reasons other than prison security and emphasizing the United States Supreme Court's statement in Schmerber... that "[t] he interests in human dignity and privacy which the Fourth Amendment protects forbid any such intrusion on the mere chance that desired evidence might be obtained." $" 125$

The court also considered the governmental interest in obtaining DNA to identify arrestees. $^{126}$ Ultimately, the court rejected the idea of obtaining DNA for identification purposes for two reasons. First, the court reasoned that DNA sampling and fingerprinting are not analogous because DNA sampling reveals more extensive personal information compared to DNA fingerprinting. ${ }^{127}$ Second, the definition of identification used by the government conflates

\footnotetext{
${ }^{120} \mathrm{Id}$.

${ }^{121}$ Id. at 782 .

${ }^{122} I d$. at $766-68$.

${ }^{123}$ Id. at 761 (quoting United States v. Kincade, 379 F.3d 813, 833-34 (9th Cir. 2004)).

${ }^{124}$ People v. Buza, 129 Cal. Rptr. 3d 753, 761 (Cal. Ct. App. 2011).

${ }^{125}$ Id. at 763 (quoting Schmerber v. California, 384 U.S. 757, 769-70 (1966) (citation omitted)).

${ }^{126} \mathrm{Id}$. at 765 .

${ }^{127}$ Id. at 767.
} 
identity verification with criminal investigation. ${ }^{128}$ The analogy between fingerprinting and DNA testing failed to consider that a DNA sample would contain the entire human genome (unlike a DNA profile), and that courts that have upheld DNA testing statutes dismissed the concern about the extent of personal information that would be available through DNA samples by mistakenly believing it to be equivalent to the information available through the DNA profile. $^{129}$ The court was cautious about the DNA profile because the presence of genetic material in "junk DNA" has been questioned. ${ }^{130}$

The court found the analogy between fingerprinting and DNA sampling to be problematic because fingerprinting was considered routine when the courts began applying the totality of the circumstances test to such situations. ${ }^{131}$ Since law enforcement began implementing fingerprinting as a routine booking procedure, it was not subject to the Fourth Amendment analysis and thus, it should not be the basis for concluding that DNA sampling is analogous to fingerprinting and therefore survives a Fourth Amendment analysis. ${ }^{132}$

Additionally, the court found that DNA statutes conflated identification and investigation but in reality, courts have distinguished between identification fingerprints and investigation

\footnotetext{
${ }^{128} I d$.

${ }^{129} \mathrm{Id}$. at 768 ("[Courts failed to consider] . . . the differences between a DNA profile and a DNA sample, including that the latter contains the entire human genome. In general, the cases upholding DNA testing statutes have dismissed concerns about the extent of the personal information contained in DNA samples by limiting their attention to the profile.").

${ }^{130}$ People v. Buza, 129 Cal. Rptr. 3d 753, 768 (Cal. Ct. App. 2011) (quoting United States v. Kincade, 379 F.3d 813, 818 n.6 (9th Cir. 2004), citing W. Wayt Gibbs, The Unseen Genome: Gems Among the Junk, SCIENTIFIC AMERICAN, Nov. 2003, at 29).

${ }^{131} I d$. at 770 ("By the time the totality of the circumstances test was announced, 'fingerprinting had long been informally deemed 'routine." "') (quoting, Corey Preston, Faulty Foundations: How the False Analogy to Routine Fingerprinting Undermines the Argument for Arrestee DNA Sampling, 19 WM. \& MARY BILL RTS. J. 475,510 (2010)).

${ }^{132} \mathrm{Id}$.
} 
fingerprints. ${ }^{133}$ Ultimately, the court held that DNA sampling is being used for criminal investigation and not for identification. ${ }^{134}$

\section{The Significance of Junk DNA and the Effects of Storage}

The significance of "junk DNA" that is used in DNA profiles is debatable. Essentially, "junk DNA" are "[t]hirteen loci (locations on the human genome) known as single tandem repeats, or 'STRs,' and are examined to produce the DNA profiles that are standard for databases in the United States." 135 The discrepancy lies in whether "junk DNA" truly is junk or is more valuable than previously thought.

Elizabeth Joh, Professor at the University of California, Davis School of Law, stated that “[t]he defense that current DNA sampling techniques target only 'junk' DNA, and thus cannot reveal medical information, should not assuage privacy concerns, however, as some markers now thought to be meaningless may be (and have been) found to contain predictive medical information as the science progresses." ${ }^{136}$ The argument against the government's retention of arrestees' DNA samples is that such samples may disclose personal family relationships, predispositions to disease, physical attributes, and ancestry. ${ }^{137}$ Adversaries point to the fact that biologists have discovered functions for some types of "junk DNA,"138 for instance, "[t]he

\footnotetext{
${ }^{133}$ Id. at 770-71 ("[For fingerprinting,] . . courts have drawn a distinction between identification-fingerprints taken 'to verify that the person who is fingerprinted is really who he says he is,' and investigation-fingerprints taken 'to connect [the person fingerprinted] to a crime with which he was not already connected."') (quoting United States v. Garcia-Beltran, 389 F.3d 864, 867 (9th Cir. 2004)).

${ }^{134} \mathrm{Id}$. at 774 .

${ }^{135}$ Simon A. Cole, Is the “Junk” DNA Designation Bunk?, 102 Nw. U. L. REV. ColloQUY 54, 56 (2007) (footnote omitted).

${ }^{136}$ Elizabeth E. Joh, Reclaiming “Abandoned” DNA: The Fourth Amendment and Genetic Privacy, 100 Nw. U. L. REV. 857, 870 (2006).

${ }^{137}$ Cole, supra note135, at 55 (citing Tania Simoncelli, Dangerous Excursions: The Case Against Expanding Forensic DNA Databases to Innocent Persons, 34 J.L. MED. \& ETHICS 390, 392 (2006)).

${ }^{138}$ Id. at 56 (footnote omitted).
} 
European DNA Profiling Group recognized early on in the application of STRs for human identity testing that 'it is likely that many or possibly most STRs will eventually be shown to be useful in following a genetic disease or other genetic trait within a family." ${ }^{\prime 139}$ Ultimately, those opposed to "junk DNA" believe that "[f]orensic STRs are potentially significant because they may turn out to be useful for predicting physical traits ... [and that] it is misleading to claim that forensic STRs have no medical significance, are devoid of information, or are completely innocuous from a privacy standpoint." ${ }^{, 140}$

Conversely, proponents of the retention of "junk DNA" state that "forensic STRs are non-functional 'junk,' [and that] the genetic data stored in databases is meaningless." 141 Additionally, recent theories do not imply that STRs have the potential to contain predictive medical information. ${ }^{142}$ In actuality, RNA molecules may be the true culprits that are transmitting parallel information and thus, it is a leap to conclude that forensic STRs (something that does not even generate RNA molecules) are capable of predicting diseases. ${ }^{143}$ Although some medical genetic researchers claim to have found a linkage between a genetic disease and a core STR marker, the findings are usually tentative, and can later be proven false; therefore, the

\footnotetext{
${ }^{139}$ John M. Butler, Genetics and Genomics of Core Short Tandem Repeat Loci Used in Human Identity Testing, 51 J. FORENSIC SCI. 253, 260 (2006).

${ }^{140}$ Cole, supra note 135 , at 59 .

${ }^{141}$ Id. at 57.

${ }^{142}$ D.H. Kaye, Science Fiction and Shed DNA, 101 Nw. U. L. REV. 62,65 (2006) (“"E]merging theories do not imply that STRs "contain predictive medical information."'). Id. at 64 ("There are various types of non-proteincoding DNA, including pseudogenes (relics of once-functioning genes), viral DNA inserted by retrotransposons, and short tandem repeats (STRs, the type of markers used in forensic identification). Recent discoveries establish that some intergenic DNA (not "markers") is biologically significant, but no forensic STR locus has been found to be predictive.").

${ }^{143} I d$. at 65 ("[RNA molecules] . . 'may be transmitting parallel information . . .' [and it would be] a leap ... [to conclude] that the forensic STRs - which do not generate RNA molecules and are not conserved across species - are functional or that their length polymorphisms will prove useful for predicting disease.") (citing Gibbs, supra note 130, at 46, 49-50 (quoting John S. Mattick)).
} 
findings should not be a reason to prevent the continued use of the STR locus. ${ }^{144}$ Proponents of “junk DNA” use believe that forensic STRs do not possess as great a threat as many may consider. $^{145}$

\section{Treatment of Abandoned DNA}

“"Abandoned DNA' is any amount of human tissue capable of DNA analysis and separated from a targeted individual's person inadvertently or involuntarily, but not by police coercion."146 The Fourth Amendment does not protect abandoned or voluntarily discarded property because any expectation of privacy that may have existed becomes irrelevant the moment it is abandoned. ${ }^{147}$ To determine whether or not a piece of property was abandoned, the Fourth Amendment test is primarily concerned with whether the owner initially possessed an expectation of privacy interest in the allegedly abandoned property. ${ }^{148}$ When dealing with abandoned DNA, proponents of the covert collection of DNA argue "that by spitting out gum, discarding a disposable coffee cup, or throwing away a used tissue," ${ }^{\prime 49}$ the individual intended to abandon the item, and any DNA that may have been contained on that item. ${ }^{150}$

\footnotetext{
${ }^{144}$ Butler, supra note 139, at 259 ("It is important to keep in mind that even though medical genetic researchers claim to have shown linkage between a particular disease gene and a core STR marker, these types of findings are often tentative and should not prevent the continued use of the STR locus ... In fact, many times these linkage "findings" can later be proven false ... ..").

${ }^{145}$ Cole, supra note 135 , at 63.

${ }^{146}$ Joh, supra note 136 , at 859.

${ }^{147}$ Williamson v. Maryland, 993 A.2d 626, 634 (Md. 2010) ("Fourth Amendment protection ... does not extend to property that is abandoned or voluntarily discarded, because any expectation of privacy in the item searched is discarded upon abandonment.").

${ }^{148} I d$. at 635 ("The test for determining whether property is abandoned for purposes of the Fourth Amendment ... focuses on whether the owner of the property retained a reasonable expectation of privacy in the article alleged to be abandoned.").

${ }^{149}$ United States v. Davis, 657 F. Supp. 2d 630, 649 (D. Md. 2009).

${ }^{150}$ Williamson v. Maryland, 993 A.2d 626, 641 (Md. 2010) (citing Davis, 657 F. Supp. 2d at 649).
} 
In Williamson v. Maryland, the court held that the DNA that was obtained from abandoned property should be construed with the reasoning proposed by the DNA proponents. ${ }^{151}$ In terms of uploading the abandoned DNA into a database, the Williamson court $^{152}$ stated that the government had a legitimate interest in identifying a person involved in a crime and had a legitimate interest in vindicating those who are falsely convicted. ${ }^{153}$ The court questioned the possibility of achieving such results if it is deemed unlawful to upload an individual's DNA sample to discover the identity of that individual. ${ }^{154}$

Similarly, in State v. Athan, ${ }^{155}$ the court held that there were no recognized privacy interests for abandoned DNA, and that the government had a legitimate purpose to collect abandoned DNA for identification purposes. ${ }^{156}$ Additionally, in Piro v. State ${ }^{157}$ the court acknowledged the power of DNA evidence and the amount of personal information it may reveal; but, the court rejected the DNA suppression motion because the court was persuaded that that although some appellate decisions (dealing with the collection of DNA from blood samples and cheek swabs from offenders) suggested that a privacy interest existed in the information that is included in a DNA databank, there were no appellate decisions that found warrantless DNA testing to be unconstitutional. ${ }^{158}$

\footnotetext{
${ }^{151} I d$. at 642.

${ }^{152}$ Williamson v. Maryland, 993 A.2d 626 (Md. 2010).

${ }^{153} \mathrm{Id}$. at 642 (" $[\mathrm{T}]$ here is a 'legitimate governmental interest in identifying persons involved with crimes, including vindicating those falsely convicted."') (quoting Maryland v. Raines, 857 A.2d 19, 43 (Md. 2004)).

${ }^{154}$ Williamson, 993 A.2d at 642.

${ }^{155}$ State v. Athan, 158 P.3d 27 (Wash. 2007).

${ }^{156}$ Id. at 43 .

${ }^{157}$ Piro v. State, 190 P.3d 905 (Idaho Ct. App. 2008).

${ }^{158}$ Id. at 911.
} 


\section{Personal AnAlysis}

Using the Fourth Amendment as a blanket that protects against every aspect of a controversial technological advancement is an unacceptable and dangerous extension of its scope. ${ }^{159}$ The Constitution cannot and will not provide a shield against every controversial technological advancement if it is reasonable; thus, if society is against a particular procedure, it is for the legislature (as a representative of society) to determine what should be allowed and the limits (if any) that should exist. ${ }^{160}$ Such is the case with DNA sampling because a blanket protection would exceed the scope of protection established by the Fourth Amendment. ${ }^{161}$ Instead, there should be restrictions on the type of information that can be obtained as opposed to restricting collection of any and all information from a DNA sample; otherwise, many similar technological advances that serve legitimate governmental interests will become unavailable due to an overbroad interpretation of the Fourth Amendment. ${ }^{162}$

\section{A. Which Test is Applicable?}

The correct test for determining the constitutionality of DNA sampling is the totality of the circumstances test. The special needs test should be reserved for "those exceptional

\footnotetext{
${ }^{159}$ See Katz v. United States, 389 U.S. 347, 350 (1967) (“[T] he Fourth Amendment cannot be translated into a general constitutional 'right to privacy."); United States v. McKeever, 5 F.3d 863, 866 (5th Cir. 1993) ("The Fourth Amendment does not provide blanket protection against searches and seizures on private property. Rather, the Fourth Amendment protects those areas in which citizens have a reasonable expectation of privacy.").

${ }^{160} \mathrm{Katz}, 389$ U.S. at 361 (Harlan, J., concurring) ("My understanding of the rule that has emerged from prior decisions is ... first that a person have exhibited an actual (subjective) expectation of privacy and, second, that the expectation be one that society is prepared to recognize as 'reasonable."') (emphasis added); Maryland v. Buie, 494 U.S. 325, 331 (1990) ("It goes without saying that the Fourth Amendment bars only unreasonable searches and seizures.") (emphasis added).

${ }^{161}$ See United States v. Mitchell, 652 F.3d 387, 390 (3d Cir. 2011) ("As arrestees have a diminished expectation of privacy in their identities, and DNA collection from arrestees serves important law enforcement interests, [the court] concludes that such collection is reasonable and does not violate the Fourth Amendment.") (emphasis added).

${ }^{162}$ See Banks v. United States, 490 F.3d 1178, 1191-92 (10th Cir. 2007) ("[T] he Act imposes stringent restrictions on the entire collection and profiling process.... These restrictions allow the Government to use an offender's DNA profile in substantially the same way that the Government uses fingerprint and photographic evidence ....").
} 
circumstances in which special needs, beyond the normal need for law enforcement, make the warrant and probable-cause requirement impracticable."163 The acquisition of a DNA sample is not as severe an intrusion into privacy as the dissent argued in Mitchell. Forced DNA extraction should be subject to a less rigorous Fourth Amendment analysis in order to better protect the Fourth Amendment's integrity when utilizing the special needs exception. ${ }^{164}$ The special needs test is reserved for non-law enforcement purposes, which is irrelevant to DNA sampling being used for law-enforcement purposes. ${ }^{165}$ Ultimately, if the courts were to implement the special needs test for DNA sampling, then every instance of sampling would need to be examined on a case-by-case basis, as the circumstances are important in determining whether the special needs exception was appropriately applied. ${ }^{166}$

\section{B. DNA Sampling and the Totality of the Circumstances Test}

Under the totality of the circumstances test, the courts will determine whether the taking of the DNA served a greater governmental interest than the injury resulting from the corresponding intrusion into the individual's privacy. ${ }^{167}$ As stated earlier, courts have considered the following factors when balancing the interests of the government and those of the individual: the extent of the intrusion, the expectation of privacy of the individual, the need of DNA

\footnotetext{
${ }^{163}$ New Jersey v. T.L.O., 469 U.S. 325, 351 (1985) (Blackmun, J., concurring).

${ }^{164}$ Charles J. Nerko, Assessing Fourth Amendment Challenges to DNA Extraction Statutes After Samson v. California, 77 FORDHAM L. REV. 917, 947 (2008) ("[U]sing a less rigorous approach in the compelled DNA extraction context will more rigorously protect the Fourth Amendment by preserving the integrity of the special needs exception.").

${ }^{165}$ United States v. Kincade, 379 F.3d 813, 823 (9th Cir. 2004) (“[Special needs] . . involve searches conducted for important non-law enforcement purposes in contexts where adherence to the warrant-and-probable cause requirement would be impracticable.").

${ }^{166}$ See id. at 828 ("“W]arrantless searches under a special needs rubric ... demands some underlying motivation apart from the government's general interest in law enforcement.").

${ }^{167}$ See United States v. Knights, 534 U.S. 112, 112-13 (2001) (“" R] easonableness is determined by assessing, on the one hand, the degree to which it intrudes upon an individual's privacy and, on the other, the degree to which it is needed to promote legitimate governmental interests.").
} 
collection as a legitimate governmental interest, the safeguards implemented, and expungement possibilities.

\section{The Extent of the Intrusion and the Arrestee's Expectation of Privacy}

Counterarguments to the governmental interest focus on the theory that arrestees possess a greater expectation of privacy than convicted felons or probationers. ${ }^{168}$ However, as mentioned earlier, courts have held that an arrestee's expectation of privacy is not free from intrusion. ${ }^{169}$ The intrusion from a DNA sample can range from a buccal swab to a blood extraction. ${ }^{170}$ These procedures do not severely intrude a person's dignity because blood tests are given during annual checkups and while donating blood, and buccal swabs are used to find potential bone marrow donors. ${ }^{171}$ These activities are standard. ${ }^{172}$ On a scale between Schmerber (where the court allowed the taking of a DNA sample over the arrestee's objection) ${ }^{173}$ to Winston (where the court did not allow the surgical intrusion of the arrestee who would be placed under general anesthesia), ${ }^{174}$ the taking of a DNA sample from an arrestee falls much

\footnotetext{
${ }^{168}$ See Julie Rikelman, Justifying Forcible DNA Testing Schemes Under the Special Needs Exception to the Fourth Amendment: A Dangerous Precedent, 59 BAYLOR L. REV. 41, 75 (2007) ("The expectation of privacy of those merely arrested of a crime is much higher than that of an individual in prison or on probation or supervised release after a conviction.").

${ }^{169}$ See Schmerber v. California, 384 U.S. 757, 771 (1966) (“'[C]onclude that the attempt to secure evidence of bloodalcohol content in this case was an appropriate incident to petitioner's arrest."); Winston v. Lee, 470 U.S. 753, 762 (1985) ("Schmerber recognized society's judgment that blood tests do not constitute an unduly extensive imposition on an individual's personal privacy and bodily integrity. Weighed against these individual interests is the community's interest in fairly and accurately determining guilt or innocence. This interest is of course of great importance.").

${ }^{170}$ Holden Memorandum, supra note 7.

${ }^{171}$ See Donating Bone Marrow, PUGET SOUND BLOOD CTR., http://www.psbc.org/programs/marrow.htm (last visited Oct. 28, 2012) (stating that a buccal swab is used to collect enough cells of the proper type); Richard Sine, Men's Health Tune-up Schedule: Medical Tests, WEBMD (MAR. 24, 2008), http://men.webmd.com/guide/menshealth-tuneup-schedule-medical-tests (stating that blood tests for diabetes are routine).

${ }_{172}$ See supra note 171.

${ }^{173}$ Schmerber, 384 U.S. at 757.

${ }^{174}$ Winston, 470 U.S. at 753.
} 
closer to the former. The arrestee is not under any anesthesia, and he does not endure any surgical intrusion; any intrusion that occurs would not be intended to obtain a piece of evidence. ${ }^{175}$ For these reasons, the procedure of taking a DNA sample does not severely intrude on an arrestee's expectation of privacy. Thus, the focus of the intrusion into privacy should be on what is taken: "junk DNA."

Presently, the "junk DNA" separated from the DNA sample serves no known purpose (other than identification). ${ }^{176}$ The possibility that "junk DNA" (more specifically the "junk DNA" taken by the FBI) ${ }^{177}$ may reveal information in the future should not serve as a bar to the entire process. If such were the case, then fingerprints should be subject to this analysis as there is a possibility that fingerprints may reveal more than is currently known. ${ }^{178}$ However, since fingerprint technology is used for identification purposes, there are no substantial concerns about the information that may be revealed through fingerprints. ${ }^{179}$ The same can be said for DNA sampling. As long as the information from a DNA sample is restricted to the" junk DNA," and is used solely for identification, there are no reasonable concerns for intrusions into privacy.

\footnotetext{
${ }^{175}$ See id. at 754 (holding that it is unreasonable to have a compelled surgical intrusion for obtaining evidence because the procedure requires the arrestee to be under general anesthesia, which results in uncertainty about the medical risks. "Surgery without the patient's consent, performed under a general anesthetic to search for evidence of a crime, involves a virtually total divestment of the patient's ordinary control over surgical probing beneath the skin.”).

${ }^{176}$ H.R. REP. No. 106-900(I), at 27 (2000) ("Moreover, the genetic markers used for forensic DNA testing were purposely selected because they are not associated with any known physical or medical characteristics, providing further assurance against the use of convicted offender DNA profiles for purposes other than law enforcement identification.").

${ }^{177}$ See Frequently Asked Questions (FAQs) on the CODIS Program and the National DNA Index System, FEDERAL BUREAU OF INVESTIGATION, http://www.fbi.gov/about-us/lab/codis/codis-and-ndis-fact-sheet (last visited Oct. 24, 2012) (stating that the thirteen loci are: CSF1PO, FGA, THO1, TPOX, VWA, DeS1358, D5S818, D7S1179, D13S317, D16S539, D18S51, D21S11).

${ }^{178}$ See Kaye, supra note 142, at 64 n.13 ("Some features of fingerprints are associated with diseases ...." (citing Julian Verbov, Clinical Significance and Genetics of Epidermal Ridges-A Review of Dermatoglyphics, 54 J. INVESTIGATIVE DERMATOLOGY 261, 261 (1970) ("Study of the patterns of the epidermal ridges of finger, palm, and sole can serve as an aid to diagnosis of many diseases ...."))).

${ }^{179}$ See Cole, supra note 135, at 61 ("“W]idespread view of fingerprints as devoid of information stems from a social decision not to invest in research exploring correlations between fingerprint patterns and race, ethnicity, disease, and behavioral propensities, not from a biological absence of such correlations.").
} 


\section{Is There a Legitimate Governmental Interest?}

Another factor to be considered when balancing both parties' interests is the governmental interest in DNA sampling. ${ }^{180}$ The most compelling governmental interest that is satisfied through the collection of DNA sampling is identification. ${ }^{181}$ DNA provides the government with the ability to identify a suspect in a crime and prevents misidentification (i.e., wrongly convicting an individual). Fingerprinting is not always a reliable method to identify the proper suspects of a crime. ${ }^{182}$ Furthermore, fingerprints can be avoided by wearing gloves, which means that it is more likely that fingerprints will not always be left at the scene of the crime, making it difficult to identify suspects. ${ }^{183}$ On the other hand, it is more difficult to avoid leaving DNA because DNA can be disposed of through skin cells, saliva, or hair. ${ }^{184}$ Resultantly, DNA is helpful in identifying a suspect in a greater number of situations and to a greater accuracy. ${ }^{185}$ The government has a legitimate interest in identifying a suspect and in preventing the wrongful accusation of an individual.

\footnotetext{
${ }^{180}$ See United States v. Mitchell, 652 F.3d 387, 403-05 (3d Cir. 2011) (stating governmental interest is a factor).

${ }^{181}$ See id. at 413 ("Most compelling is the Government's strong interest in identifying arrestees.").

${ }^{182}$ See Jason Felch, Solving Crimes Using Fingerprints is an Inexact Science, L.A. TIMES, Mar. 20, 2009, available at http://articles.latimes.com/2009/mar/20/opinion/oe-felch20 ("In 2004, the Boston Police Department was forced to shut down its fingerprint lab after a 'glaring mistake' led to a wrongful conviction. That same year, the FBI's top fingerprint analysts were forced to admit that they were wrong after claiming to be 'absolutely confident' that a fingerprint had linked a lawyer in Oregon to the Madrid train bombings.").

${ }^{183}$ See Corinna Kruse, Forensic Evidence: Materializing Bodies, Materializing Crimes, 17 EuR. J. Women's STUD. 363, 367 (2010) (“Criminals can (and often do) wear gloves, which prevent leaving fingerprints; not everyone's touch leaves equally distinct traces; nor do all surfaces receive and retain fingerprints, and sufficiently clear fingerprints at that, equally well.").

${ }^{184} I d$. ("[T] races that contain DNA are not rare. Expelling tiny droplets of saliva when speaking, or shedding skin cells leave traces that contain DNA.").

${ }^{185}$ See Advancing Criminal Justice Through DNA Technology, DNA INITIATIVE, http://www.dna.gov/basics/ (last visited Oct. 28, 2012) (stating that each person has a unique DNA and that DNA can be used to solve previous unsolvable cases and implicate or eliminate a suspect).
} 


\section{With Sufficient Safeguards, are Warrants Even Necessary?}

The Buza Court proposed a broader solution that, if taken, may serve as the proper intermediate step that would help protect the rights of arrestees while still allowing the benefits of DNA sampling. ${ }^{186}$ However, judicial intervention is an unnecessary step because DNA samples are only taken upon arrest and, in order to arrest an individual, a law enforcement officer must have probable cause. ${ }^{187}$ At the point of arrest, since the officer has to have probable cause to detain an individual for a period of time, the arrestee no longer enjoys the same expectation of privacy as an ordinary citizen. ${ }^{188}$ Additionally, "[a] warrant requirement will not make much difference to a society that, under the sway of a naive and discredited theory of genetic determinism, is willing to lock people away on the basis of their genes." ${ }^{\text {189 }}$ Since genetics already plays a vast role in society for convicting an individual, requiring a warrant to take a DNA sample in order to verify whether an individual is the proper suspect, would be counterintuitive to the society's reliance on genetics. Furthermore, judicial intervention is an unnecessary step that will result in judicial inefficiency. The proper step is to impose restrictions such as statutes limiting collection of DNA to "junk DNA.” Much like other DNA statutes,

\footnotetext{
${ }^{186}$ See People v. Buza, 129 Cal. 3d. 753, 783 (Cal. Ct. App. 2011) (“'[T]o the extent it requires felony arrestees to submit a DNA sample for law enforcement analysis and inclusion in the state and federal DNA databases, without independent suspicion, a warrant or even a judicial or grand jury determination of probable cause, unreasonably intrudes on such arrestees' expectation of privacy and is invalid under the Fourth Amendment ....").

${ }^{187}$ See Gerstein v. Pugh, 420 U.S. 103, 111 (1975) ("The standard for arrest is probable cause, defined in terms of facts and circumstances 'sufficient to warrant a prudent man in believing that the (suspect) had committed or was committing an offense." (citing Beck v. Ohio, 379 U.S. 89, 91 (1964))).

${ }^{188}$ See United States v. Pool, 645 F. Supp. 2d 903, 910 (E.D. Cal. 2009) (“An arrestee has a diminished expectation of privacy in his own identity. Probable cause has long been the standard which allowed an arrestee to be photographed, fingerprinted and otherwise be compelled to give information which can later be used for identification purposes."); Jones v. Murray, 962 F.2d 302, 306 (4th Cir. 1992) ("[W]hen a suspect is arrested upon probable cause, his identification becomes a matter of legitimate state interest and he can hardly claim privacy in it. We accept this proposition because the identification of suspects is relevant not only to solving the crime for which the suspect is arrested, but also for maintaining a permanent record to solve other past and future crimes.").

${ }^{189}$ Kaye, supra note 142, at 66.
} 
Congress can limit the crimes for which, DNA may be collected from arrestees. ${ }^{190}$ "The public can decide for itself whether and to what extent, the privacy risk offsets the benefits of genetic databases."191 In that line of thought, it is up to Congress to control the use of DNA sampling, not the judiciary.

It is a logical argument that a search warrant or judicial intervention would prevent abuse but it does not have much weight. The Pool court recognized that the statute already existed as an intermediate step to prevent abuse. ${ }^{192}$ The protections from the statute prevent a majority of individuals from taking advantage of private information and though not everyone will be deterred, that is no reason to decline to implement a procedure, as there is no sanction that can deter every possible violator. ${ }^{193}$ If the fact that all violators are not deterred by sanctions was sufficient to dismiss procedures, then medical records could not be computerized because of the potential for someone to hack into the records. ${ }^{194}$ The point is that "[o]ur modern technological society cannot function in an atmosphere of privacy paralysis occasioned by a parade of "what ifs." 195

With the DNA Act, the statute imposes penalties on improper use of the DNA information. For instance, if a person, "by virtue of employment or official position, has possession of, or access to individually identifiable DNA information [and] . . knowingly

\footnotetext{
${ }^{190}$ See State DNA Database Laws Qualifying Offenses, DNA RESOURCE (Sept. 2011), http://www.dnaresource.com/documents/statequalifyingoffenses2011.pdf (outlining the 50 states qualifying offenses for when a DNA sample can be taken from an arrestee).

${ }^{191}$ Cole, supra note 135 , at 63.

${ }^{192}$ Pool, 645 F. Supp. 2d at 912 ("Defendant's argument that no data sequestration system is immune from abuse is no reason to disallow DNA identification sampling. The point is that such information cannot be used outside of the statute's permissible purpose on pain of criminal penalties.").

${ }^{193} I d$.

${ }^{194} I d$.

${ }^{195} I d$.
} 
discloses such information," that person will be fined not more than $\$ 100,000 .{ }^{196}$ Similarly, "[a] person who knowingly discloses a sample or result [under $\S 14135]$. . . shall be fined not more than $\$ 250,000$, or imprisoned for a period of not more than one year."197 Besides use and disclosure, the Act also protects against unlawfully obtaining the DNA information. "A person who, without authorization, knowingly obtains DNA samples or individually identifiable DNA information indexed in a database . . shall be fined not more than $\$ 250,000$, or imprisoned for a period of not more than one year, or both."198 Besides these criminal penalties, the statute implements other safeguards to ensure the correct use of DNA sampling. ${ }^{199}$ Additionally, not only are there safeguards against the use and disclosure of DNA samples, but also against the laboratories that participate in the index system. ${ }^{200}$ These safeguards exist to ensure that the DNA samples remain private and that they are properly used. ${ }^{201}$ Furthermore, the safeguards in conjunction with the use of "junk DNA" render the requirement of a warrant or judicial intervention superfluous and redundant. Congress (being representatives of society) has deemed DNA sample extraction to be reasonable. If society does not agree with the legislation imposed by Congress, it should reach

\footnotetext{
19642 U.S.C. $\$ 14133(c)(1)(2006)$.

${ }^{197} 42$ U.S.C. $\S 14135 \mathrm{e}(\mathrm{c})(2006)$.

19842 U.S.C. $\$ 14133(c)(2)(2006)$.

${ }^{199}$ See 42 U.S.C. $§ 14133$ (b) (2006) (stating that DNA test results can only be disclosed for identification purposes to criminal justice agencies, judicial proceedings, and criminal defense purposes); 42 U.S.C. § 14132(b) (2006) (stating the index is only to include information on DNA identification records and DNA analyses subject to certain standards); 42 U.S.C. $§ 14132$ (c) (2006) ("Access to the index established by [§ 14132] is subject to cancellation if the quality control and privacy requirements ... are not met.").

${ }^{200}$ See M. Dawn Herkenham, Retention of Offender DNA Samples Necessary to Ensure and Monitor Quality of Forensic DNA Efforts: Appropriate Safeguards Exist to Protect the DNA Samples from Misuse, 34 J.L. MED. \& ETHICS 380, 383 (2006) ("All laboratories participating in the National DNA Index System are required to generate their DNA records in accordance with the FBI Director's Quality Assurance Standards for Forensic DNA Testing Laboratories and Quality Assurance Standards for Convicted Offender DNA Databasing Laboratories. These standards require that laboratories undergo an annual audit to monitor compliance with the standards. At least once every two years, the audits must be conducted by persons external to the agency .....").

${ }^{201}$ See id. ("[E]xisting laws for confidentiality and limited disclosure serve as a balance against any potential for misuse of the DNA samples collected in connection with state and national offender DNA databases.").
} 
out to its representatives for changes, instead of attempting to extend the scope of the Fourth Amendment. In the future, courts interpreting any similar state or Federal DNA statutes should focus on the accompanying statutes that impose restrictions and criminal penalties on DNA collection, rather than trying to reach beyond the protections of the Fourth Amendment. The proper safeguards that the courts should implement are restricting DNA collection to only those individuals who have been arrested on probable cause, and restrict the content to only "junk DNA." The "What Ifs" with "junk DNA" should not be taken into consideration unless there has been (if ever) definitive research proving that the "junk DNA" collected by Law Enforcement officials actually serves a more intimate purpose than identification. ${ }^{202}$ Anything different would result in unconstitutionality under the Fourth Amendment because the extent of what fingerprints can reveal is not yet completely known. ${ }^{203}$

The Fourth Amendment cannot serve as a blanket protection for controversial issues that may arise. Safeguards exist to protect areas that are outside the reach of the Fourth Amendment. If these safeguards are insufficient, then it is up to the citizenry to convince the legislature to either request new safeguards or eradicate the act altogether.

\section{Why DNA is a Natural Progression from Fingerprints}

The argument that DNA sampling is not a natural technological progression from fingerprints does not take into account the significant advances in fingerprint technology. With more research devoted to fingerprinting technology, the quantity and type of information that may be revealed via fingerprints could be significant. For instance, latent fingerprints may be

\footnotetext{
${ }^{202}$ See United States v. Pool, 645 F. Supp. 2d 903, 912 (E.D. Cal. 2009) (“'Our modern technological society cannot function in an atmosphere of privacy paralysis occasioned by a parade of "what ifs."').

${ }^{203}$ Kaye, supra note 142, at 64.
} 
able to reveal drug abuse. ${ }^{204}$ The sweat that excretes from the skin's pores can be transferred, leaving unique impressions. ${ }^{205}$ Furthermore, if more finances were devoted to fingerprints, drugs would not be the only aspect detectable from fingerprints. ${ }^{206}$ "Cancer, diabetes, heart disease and other medical conditions produce specific chemicals also secreted in sweat and oil. By tweaking the antibodies on the particles, forensic scientists could test for a variety of medical conditions." 207 Granted, these fingerprints are not exactly the same as those taken during a booking procedure after an arrest. However, as technology advances, so do the methods of obtaining fingerprints, which could make fingerprints more reliable and in essence begin to reveal more information. ${ }^{208}$

Additionally, genetic exceptionalists argue that DNA is too unique to be analogous to fingerprints and therefore, it warrants its own analysis. ${ }^{209}$ However, genetic exceptionalism fails to consider the ability of fingerprints to contain hereditary information. ${ }^{210}$ Those against the genetic exceptionalists' views argue that the full capabilities of fingerprints are not yet certain, stating that "the widespread view of fingerprints as devoid of information stems from a social decision not to invest in research exploring correlations between fingerprint patterns and race,

\footnotetext{
${ }^{204}$ See Otto S. Wolfbeis, Nanoparticle-Enhanced Flurescence Imaging of Latent Fingerprints Reveals Drug Abuse, 48 ANGEW. CHEM. INT. ED. 2268, 2268 (2009) (stating that the use of nanoparticle-enhanced fluorescence imaging of fingerprints may reveal drug abuse).

${ }^{205} I d$. ("'Sweat] . . . is excreted through the pores in the skin and deposited on the surface of the skin, from where it can be transferred to another surface ... leave[s] an impression on the ridge pattern ... [which is unique.]").

${ }^{206}$ See Cole, supra note 135, at 61 ("[T] he widespread view of fingerprints as devoid of information stems from a social decision).

${ }^{207}$ Eric Bland, Fingerprints Can Reveal Drug Use, Medical History, DisCOVERY NEWs (Dec. 10, 2008), http://dsc.discovery.com/news/2008/12/10/fingerprint-drugs.html.

${ }^{208}$ See Messmer, supra note 27 (discussing the FBI's switch to the Advanced Fingerprint Information Technology which goes "beyond fingerprint identification to other biometrics, including latent palm prints and facial recognition.”); Alice Lipowicz, FBI Deploys Faster Fingerprint ID System, Gov’T COMPUTER News (Mar. 9, 2011), http://gcn.com/articles/2011/03/09/fbi-deploys-faster-fingerprint-identification-system.aspx (stating that the FBI's "Next Generation Identification System provides automated fingerprint and latent search capabilities, storage and electronic data exchange.").

${ }^{209}$ Joh, supra note 136 , at 869 .

${ }^{210}$ Cole, supra note 135 , at 61 ("“G]enetic exceptionalism incorrectly portrays fingerprints as devoid of hereditary information.").
} 
ethnicity, disease, and behavioral propensities, not from a biological absence of such

correlations. ${ }^{211}$ In fact, there are features in fingerprints that are associated with diseases. ${ }^{212}$

Thus, fingerprints reveal more information than just identity. ${ }^{213}$

Essentially, "fingerprint identification technology" is separated from the technology that would allow fingerprints to reveal much more information than identification. CODIS separates DNA that is used for identification purposes from the DNA that reveals greater personal information about an individual. ${ }^{214}$ Thus, the analogy that DNA sampling is a natural technological progression of fingerprints is accurate if one were to concentrate on exactly what DNA sampling focuses on: identification. ${ }^{215}$

Then, the natural question is if there are technological advances in fingerprint technology, why do law enforcement groups need DNA “fingerprints"? As previously stated, identifying an individual that committed a crime is not always an easy task (at least when implementing traditional methods such as fingerprints), and many criminals use gloves to cover up their fingerprints or only leave partial prints at the scene of the crime. ${ }^{216}$ DNA sampling allows for

\footnotetext{
${ }^{211} I d$.

${ }^{212}$ Kaye, supra note 142, at 64 (footnote omitted) ("Some features in fingerprints are associated with diseases, and research into this aspect of dermatoglyphics continues to this day.").

${ }^{213} I d$. ("[The] assertion that fingerprints "cannot reveal any more information [than identity] about the person from whom they have been collected' is mistaken.”) (citing Joh, supra note 136, at 870).

${ }^{214}$ See H.R. REP. No. 106-900(I), at 27 (2000) ("'[T] he effect of the system is to provide a kind of genetic fingerprint which uniquely identifies an individual, but does not provide a basis for determining or inferring anything else about the person.").

${ }^{215}$ But see Corey Preston, Faulty Foundations: How the False Analogy to Routine Fingerprinting Undermines the Argument for Arrestee DNA Sampling, 19 WM. \& MARY BILL RTS. J. 475, 476 (2010) (“[T]he 'technological progression' argument ignores the obvious conclusion that with 'progression' comes legitimate substantive differences between the two types of evidence, and the intrusions on privacy those differences represent.").

${ }^{216}$ See Kruse, supra note 183, at 367 (2010) ("Criminals can (and often do) wear gloves, which prevent leaving fingerprints; not everyone's touch leaves equally distinct traces; nor do all surfaces receive and retain fingerprints, and sufficiently clear fingerprints at that, equally well.”).
} 
greater reliability, greater opportunity to identify the suspect, and a greater protection against wrongly accusing an individual. ${ }^{217}$

\section{Abandoned DNA and DNA Sampling}

As stated, courts should focus not on the procedure or process of taking DNA, but rather on what is taken. Therefore, it makes sense to relate DNA sampling to abandoned DNA because in both instances, DNA is taken. The main difference between abandoned DNA and DNA obtained after arrest is that with abandoned DNA, the individual is unaware about his DNA being collected and law enforcement could indefinitely keep his DNA in the records without that individual's knowledge, while with the DNA obtained after arrest, the individual is aware that law enforcement took his DNA and he can expunge the DNA records pursuant to 42 U.S.C. $\S$ 14132(d)(1)(A) (if there was no conviction). ${ }^{218}$ If there are no privacy concerns that arise from abandoned DNA and no restrictions on abandoned DNA, then DNA sampling of arrestees should be considered less of a concern. ${ }^{219}$ Theoretically, if DNA sampling of arrestees is not allowed, police could follow an individual around, wait for that individual to dispose of a DNA sample and then collect it before the arrest. ${ }^{220}$ With the current DNA statute, there are specific protections that are not afforded with abandoned DNA collection. ${ }^{221}$

${ }^{217}$ DNA Evidence Basics, NATIONAL Institute OF Justice (Aug. 9, 2012), http://www.nij.gov/topics/forensics/evidence/dna/basics/welcome.htm (stating that each person has a unique DNA pattern which can be used to implicate or eliminate a suspect in criminal investigations).

${ }^{218}$ See 42 U.S.C. $§ 14132$ (d)(1)(A)(ii) (2006) (stating that the DNA analysis of a person should be expunged from the index when "a certified copy of a final court order establishing that such charge has been dismissed or has resulted in an acquittal or that no charge was filed within the applicable time period.").

${ }^{219}$ See State v. Athan, 158 P.3d 27, 43 (Wash. 2007) ("No recognized privacy interest exists in voluntarily discarded saliva and a legitimate government purpose in collecting a suspect's discarded DNA exists for identification purposes.").

${ }^{220}$ See Williamson v. Maryland, 993 A.2d 626, 641 (Md. 2010) (“'[T] he voluntary abandonment of the McDonald's cup did not implicate an unconstitutional seizure under the Fourth Amendment.”).

${ }^{221}$ See Frequently Asked Questions (FAQs) on the CODIS Program and the National DNA Index System, FEDERAL BUREAU OF INVESTIGATION, http://www.fbi.gov/about-us/lab/codis/codis-and-ndis-fact-sheet (last visited Oct. 26, 


\section{CONCLUSION}

Under the totality of the circumstances test, the governmental interest is balanced against the individual's interest in privacy. The government has a legitimate interest in collecting DNA samples from arrestees as it is necessary for identification. There is no question as to whether DNA sampling constitutes a search, but the procedure of collecting DNA is not intrusive or unconstitutional; rather the constitutionality of DNA sampling rests on the material seized. The fact that the material seized is "junk DNA" - combined with the safeguards implemented in the DNA Act, the governmental interest and the diminished expectation of privacy of arresteeseliminates the necessity of a warrant to obtain a DNA sample and removes any Fourth Amendment violation concerns. The Fourth Amendment should not be a blanket protection for controversial issues that may arise. Preferably, if the issue is outside the protection of the Fourth Amendment, then it is up to Congress to establish the proper safeguards to prevent any abuse that may arise. If those safeguards are insufficient, then the people must voice their opinion and either demand amendments to those safeguards or removal of the Act altogether. Under the totality of the circumstances, DNA fingerprinting meets the requirements of the Fourth Amendment and therefore, it is constitutional.

2012) ("Access to [computers containing CODIS] is limited to only those individuals authorized to use CODIS and approved by the FBI. Communications between participating federal, state, and local laboratories occur over a wide area network accessible to only criminal justice agencies approved by the FBI. Pursuant to federal law ... DNA data is confidential. Access is restricted to criminal justice agencies for law enforcement identification purposes.”). 